\title{
INFLATION AND MONETARY POLICY IN JUNE 2013
}

\author{
A.Bozhechkova
}

In June 2013, the consumer price index stood at 0.4\% (against 0.9\% in June 2012), being 0.3 p.p. less than in May 2013. The consumer price index reached 0.8\%. within the first 20 days in July 2013. Therefore, inflation exceeded $6.9 \%$ on a year-on-year basis. According to Bank of Russia's preliminary estimates, net capital outflow from the country reached \$10bn in Q2 2013, and totaled \$38,4bn in H1 2013, being \$1,7bn less year-on-year.

Consumer-price inflation slowed down in June 2013: consumer price index stood at $0.4 \%$ late in the month (in May 2013 0.7\%), having dropped below $0.9 \%$ against 2012 . As a result, inflation reached $6.9 \%$ on a year-on-year basis (Fig. 1). Core inflation ${ }^{1}$ stood at $0.3 \%$ in June 2013 , having lost 0.1 p.p. against the previous year.

In June 2013, inflation was mitigated by slower growth in prices of food products (from 1.0\% in May to $0.5 \%$ in June on a year-on-year basis) due to slower growth rate in prices of fruits and vegetables (from $6.5 \%$ in May to $3 \%$ in June on a year-on-year basis), sugar and granulated sugar (from $2.0 \%$ in May to $1 \%$ in June on a year-on-year basis), fish and seafood (from $0.6 \%$ in May to $0.4 \%$ in June on a year-on-year basis). In June, prices of food products such as sun flower oil, meat and poultry, eggs dropped by $0.1 \%, 0.2 \%$, and $10.5 \%$ respectively, whereas there was an increase of growth rates in prices of bread and flour products (from $0.4 \%$ in May to $0.5 \%$ in June on a year-on-year basis) and butter (from $0.4 \%$ in May to $0.7 \%$ in June on a year-on-year basis).

Growth rate in prices and tariffs of paid services to the public increased by $0.6 \%$ in June, having declined by $0.8 \%$ below the May value. Prices of passenger transport services increased $1.9 \%$ due to a vacation season: carfare in long-distance trains increased. Prices of sanitary and health-improvement services and foreign travel services kept growing, by $4.9 \%$ and $2.4 \%$ respectively. Prices of consumer services increased by $0.5 \%$ and medical services by $0.6 \%$.

Growth rate of prices of non-food products slowed down in June against May $2013(0.2 \%$ in June $(+0.3$ in May). Prices of the following products increased most in this product family: tobacco products by $1.6 \%$ (against 3.2 in May 2013) and medications by $0.6 \%$ (against 0.9 in May 2013). Prices of audio-video prod-

1 Reference consumer price index is an indicator which describes the level of inflation in the consumer market, net of seasonal (prices of fruit and vegetable products) and administrative (tariffs of regulated types of service, etc.) factors which is also calculated by the Federal State Statistic Service of Russia (Rosstat).

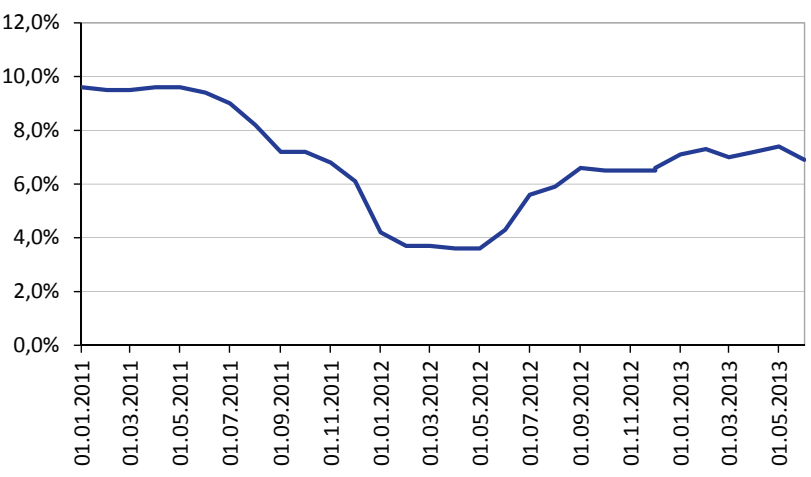

Source: Rosstat.

Fig. 1. CPI growth rate in 2011-2013 (\% year over year)

ucts and gasoline kept falling in June, by $0.1 \%$ and $0.2 \%$ respectively, in the non-food product family.

Within the first 20 days in July consumer price index (CPI) stood at $0.8 \%$ basically in response to indexation of public utility rates early in the month. As a result, the accumulated since the beginning of the year inflation reached $4.3 \%$, (against $4.4 \%$ in the same period of 2012). As of June 20,2013 , inflation exceeded $6.9 \%$ on a year-on-year basis.

Prices might further be pushed up by anticipated crop decline due to adverse weather conditions in certain regions (a drought in some of the south regions, in the northern part of the Volga Region, and a rainy weather in the Central Federal District). Poor domestic demand which has been weakening over a year, and continued slowdown in growth rates in money supply (M2 increased at a rate of $20.9 \%$ year-on-year as of June 1,2012 to $15.3 \%$ as of June 1,2013 ) will be inflation constraining factors.

In June 2013, broad money increased by $3.2 \%$, Rb 9063,2bn, on a year-on-year basis (Fig. 2). All broad money components saw growth. Cash in circulation, including cash balances in credit institutions, increased by $1.9 \%$ ( $R b 7419,6 b n$ ) on a year-on-year basis. Correspondent accounts increased by $12.2 \%$ (Rb 1002,4bn) on a year-on-year basis, mandatory reserves by $2.2 \%$ ( $\mathrm{Rb} 497,7 \mathrm{bn}$ ) on a year-on-year basis, banks' deposits 
with the Central Bank of Russia by 15.4\% (Rb 143,5bn) on a year-on-year basis.

In June 2013, narrow money (cash plus ) gained 2\% (Rb 7917,3bn) on a year-on-year basis (Fig. 3).

In June 2013, commercial banks' excess reserves ${ }^{1}$ increased in volume by $12.6 \%$ ( $R b 1145,9 b n$ ) on a yearon-year basis, and banks' debt on repo transactions increased $7.8 \%$ to reach $\mathrm{Rb} 2,19$ trillion. According to the data on July 25 , banks owed $\mathrm{Rb} 2,26$ trillion on repo transactions (Fig. 2). The interbank lending market interest rate ${ }^{2}$ stood at an average of $6.3 \%$ in June $16.37 \%$ in May 2013). The interest rate stood $6.01 \%$ on average between July 1 and 24 .

As of July 1, 2013, the Central Bank international reserves amounted to $\$ 513,8 \mathrm{bn}$, having declined by $4.4 \%$ since the beginning of the year (Fig. 3). In Q1 2013, Russia's USD international reserves contracted basically in response to USD strengthening vs. EUR. Further contraction of the international reserves in May with insignificant foreign currency net sale by the Bank of Russia was governed by EUR strengthening vs. USD due to uncertainty about FRS's policy tightening and anticipated European economic recovery. The contraction of the international reserves in June was caused by a negative revaluation of gold and euro, as well as Central Bank's currency interventions.

In June 2013, Central Bank's currency interventions amounted to $\$ 2707,6 \mathrm{~m}$ and $245,7 \mathrm{~m}$ euro and were aimed at smoothing ruble exchange rate volatility in periods of its rapid weakening (Fig. 4).

Bank of Russia's preliminary estimates show that net capital outflow from Russia reached $\$ 10 \mathrm{bn}$ in Q2 2013 and totaled $\$ 38,4 \mathrm{bn}$ in H1 2013, having shown a contraction of $\$ 1,7 \mathrm{bn}$ against $\mathrm{H1} 2012$. In the period between January and June 2013, net capital outflow in banks amounted to $\$ 19,4 \mathrm{bn}$, in other sectors $-\$ 18,9 \mathrm{bn}$.

In June 2013, the real effective ruble exchange rate increased by $3.3 \%$ vs. foreign currencies $(+1.1 \%$ in May 2013) (Fig. 5). In Q2 2013, the real effective ruble exchange weakened by $1.7 \%$.

The USD/RUB exchange rate in June increased by $2.87 \%(\mathrm{Rb} 32,7)$ on a year-on-year basis in response to capital outflow from emerging markets due to continued uncertainty about discontinuance of the FRS quantitative easing program. The EUR/RUB exchange rate grew up 3.06\% in June 2013 (Rb 42,7). In June, the EUR/USD exchange rate stood at 1.32 on ave-

1 Commercial banks' excess reserves with the Central Bank refer to the amount of commercial banks' correspondent accounts, their deposits with the Central Bank, as well as Central Bank bonds held by commercial banks.

2 Interbank interest rate is the monthly average MIACR, an interest rate on ruble overnight interbank loans.

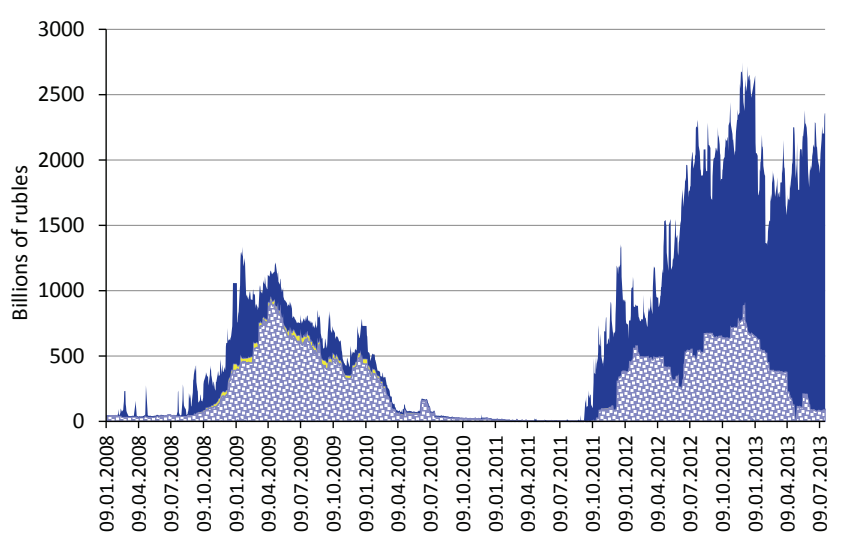

— Overnight loans $\quad$ 圈 Other loans' debt $\square$ Lombard loans' debt $\square$ REPO debt

Fig. 2. Commercial banks' debt owed to the Bank of Russia in 2008-2013

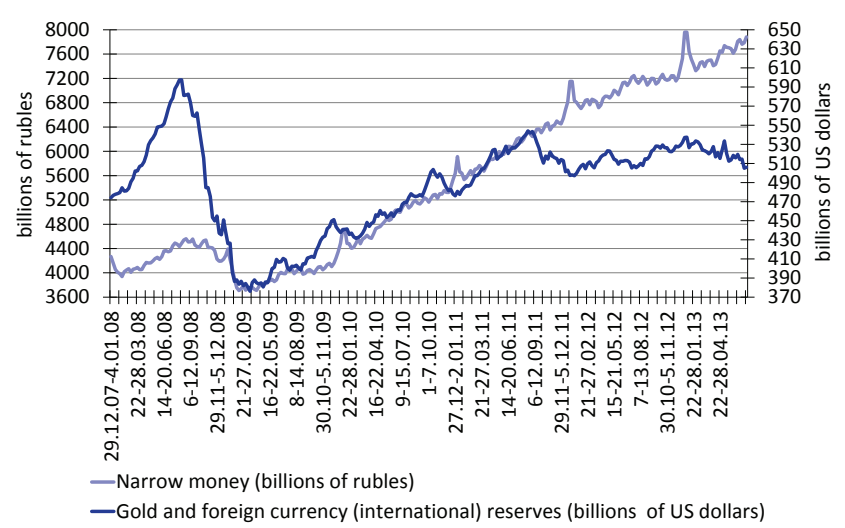

Fig. 3. Dynamics of narrow money and gold and foreign currency (international) reserves of the Russian Federation in 2007-2013

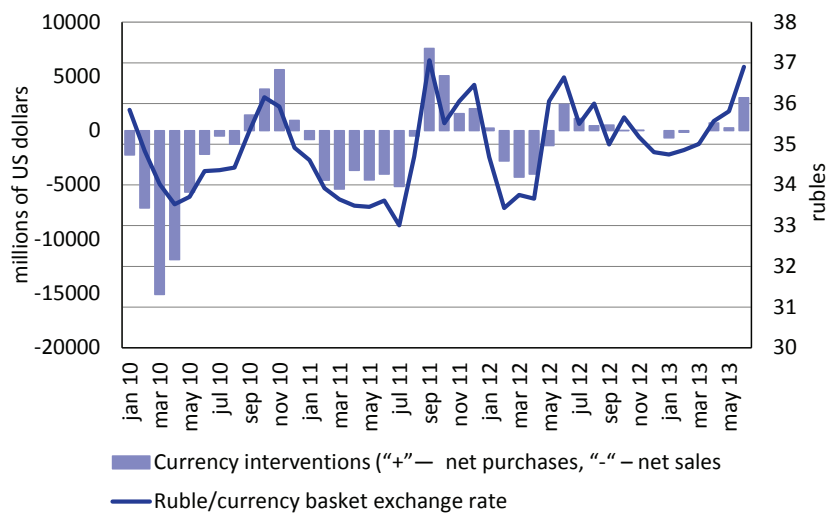

Source: the Central Bank of Russia, author's estimates. Fig. 4. Bank of Russia's currency interventions and ruble/ currency basket exchange rate in March 2010 - June 2013 
rage. In June, the cost of the dual currency basket increased by $2.97 \%(\mathrm{Rb} 37,2)$ on a year-on-year basis. Within 25 days in July 2013, the USD/RUB exchange rate dropped by $1.5 \%$ to reach $\mathrm{Rb} 32,3$ while the EUR/ RUB exchange rate dropped by $0.2 \%$ to reach $\mathrm{Rb} 42,7$, thereby having reduced the cost the dual currency basket by $0.8 \%(\mathrm{Rb} 37,0)$ on a year-on-year basis. Within 25 days in June 2013, the EUR/USD exchange rate stood at 1.3 on average. The Bank of Russia Board of Directors held its regular meeting on July 12, 2013, at which Central Bank's basic interest rates were left unchanged. However, the Bank of Russia announced a new refinancing instrument for the banking system auctions on loans secured by non-market assets or guarantees with a term of 12 months. It should be noted that the Central Bank for the first time held a press conference after its Board of Directors regular meeting, at which it was announced a limit $\mathrm{Rb} 500 \mathrm{bn}$ for the initial auction scheduled for July 29, 2013. Furthermore, according to the Central Bank, the new instrument is designed to reallocate refinancing volume in favor of longer-term instruments rather than promote its growth. Therefore, limits on overnight repo auctions may be reduced by a comparable value. A minimum interest rate on the new refinancing instrument will be $5.75 \%$ p.a., i.e. it will be 0.25 p.p. above the minimum rate on overnight repo auctions. In addition, the Central Bank of Russia promised to promptly evaluate collaterals.

It should be noted that it basically is collateral evaluation procedures and discounts that should make

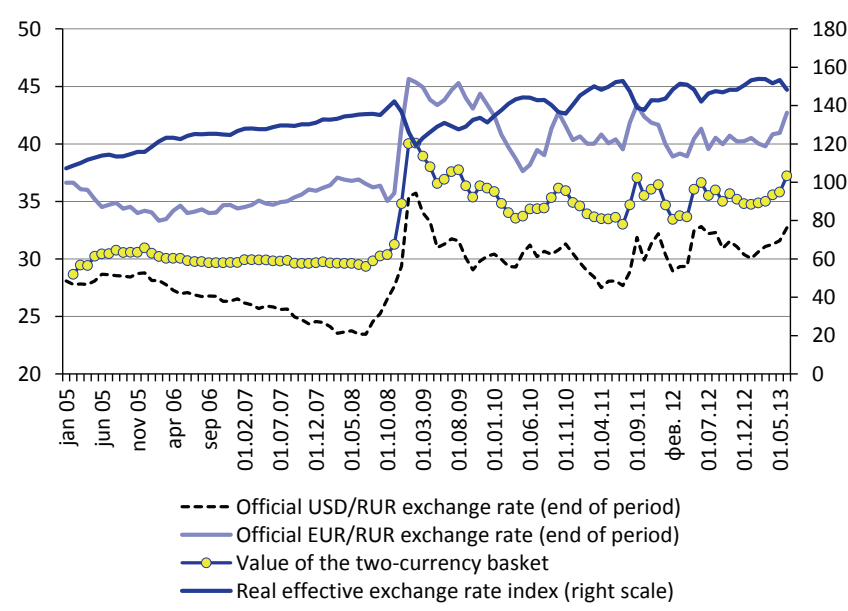

Source: the Central Bank of Russia, author's estimates.

Fig. 5. Ruble exchange rate indicators in January 2005 thru June 2013

the new instrument attractive for banks. Indeed, in general it is possible to change refinancing structure in favor of long-term instruments, but we believe that given the current macroeconomic situation with high rate of employment and inflation, monetary policy easing would not produce substantially positive results. Furthermore, it is not the central bank but the financial system that is supposed to create long money in the economy. In other words, most efficient options for economic activity stimulation will include mitigation of inflation risks, development of institutional environment, and enhancement of the financial sector depth. 